\title{
Trust gives warm welcome to open access
}

Jim Giles, London

The Wellcome Trust, Europe's largest research charity, has become the latest grant-giving body to throw down the gauntlet to academic publishers in the debate over open-access literature.

All papers reporting the results of research funded by the trust will in future have to be placed in a central public archive within six months of publication, the organization said on 4 November. The move could bring the trust into conflict with publishers, who often hold exclusive rights on the use of such material. This in turn could restrict researchers' choices about which journals they publish in.

But advocates of open access suffered a setback on 8 November when the British government rejected proposals for reforms favouring open access. The proposals had been made in July by the House of Commons Science and Technology Committee (see Nature 430, 390; 2004).

In particular, the government rejected the committee's call that it should instruct its research councils to provide money so that scientists could meet author charges in open-access journals. "The government does not think it should intervene to support one model or another," it said in a formal response to the committee report, adding that it was "also not convinced that the 'author-pays' model is inherently superior to the current model".

But the Wellcome Trust says that it may now establish a European version of PubMed

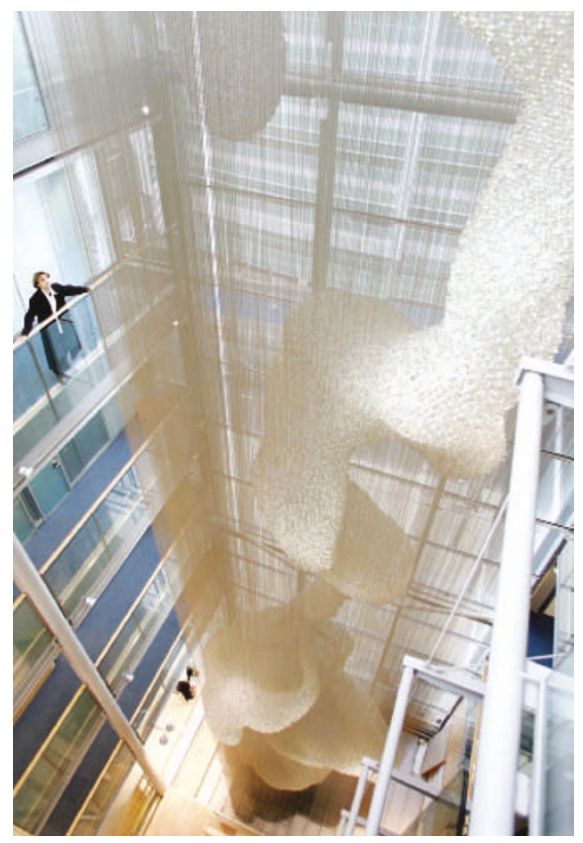

The Wellcome Trust's new London HQ: the charity has set out plans for open-access publishing.

Central, a US database of biomedical research. Wellcome officials are already talking about this possibility to the US National Library of Medicine, which runs PubMed Central, but have not set a date for creating such an archive. The trust is preparing to set aside $1-2 \%$ of its total annual spend of $\mathfrak{} 400$ million (US\$740 million) to cover the costs of the archive and of uploading papers. The version uploaded would not necessarily be the publisher's final version.

Researchers funded by Wellcome could find that the new rules create some difficult choices. Some publishing houses, such as Elsevier, which publishes more than 1,800 journals including Cell and The Lancet, do not currently allow any version of a paper they have published to be placed on a public archive other than on websites restricted to the author's research institution.

"This will put publishers and researchers in a difficult position," acknowledges Robert Terry, a senior policy adviser at the trust's London headquarters. But Terry believes that journals will modify their policies to allow papers to go to central archives. $\mathrm{He}$ points out that the US National Institutes of Health (NIH) is considering putting similar requirements on the research that it funds (see Nature 431, 115; 2004). "It would be quite a strange journal that didn't include research funded by the NIH and the Wellcome Trust," he adds.

A spokeswoman for Elsevier said that the company was watching the NIH and Wellcome developments with interest but would not comment on possible changes to its copyright rules. Annette Thomas, managing director of Nature Publishing Group (NPG), which publishes Nature, says that important questions about the archive, such as who would take responsibility for the accuracy of the submissions, need to addressed before NPG can take a position on the plan.

\section{Leukaemia sleuths accuse state of nuclear cover-up}

\section{Barbara Simm, Munich}

A 12-year-long investigation into a possible nuclear link to childhood leukaemia in northern Germany took a bizarre turn last week. On 8 November, six members of an eight-strong expert commission resigned, accusing the local authorities of covering up a fire at an alleged secret nuclear lab.

The startling accusation got prime-time media attention throughout Germany. State officials immediately rejected it as a "weird conspiracy theory", and announced that they would bring legal charges against Otmar Wassermann, a retired toxicologist at the University of Kiel who chaired the investigation.

The state government of SchleswigHolstein in 1992 asked the commission to investigate the cause of an unusual cluster of leukaemia cases in the vicinity of the Krümmel nuclear power plant near Hamburg. Between 1989 and 1991, six cases of childhood leukaemia in the area put incidence about ten times higher than the German average. Today, the number of new cancer cases has dropped, but is still above average.

In 1996, a report from the Öko Institute — an independent environmental research institute critical of nuclear energy — ruled out a link to a reactor operated by the nearby GKSS research centre (see Nature $384,398 ; 1996)$. Now the members of the Wassermann commission who resigned have added that the cluster cannot be blamed on the nuclear power plant either.

Wassermann claims to have found traces of radioactive products, including americium and plutonium isotopes, in soil near the GKSS centre. He says that the traces don't come from either Chernobyl fallout or from atomic bomb tests. Instead he suspects that the GKSS carried out "secret nuclear experiments" in the 1980s; a fire may then have released nuclear contamination that caused the cancer cluster, he says. An old aerial photo of the area shows a building that Wassermann takes to be a secret lab.

Hans-Friedrich Christiansen, a spokesman for the GKSS, denies that any kind of secret or unauthorized experiments have ever been carried out at the centre, and says that there has never been a large fire. The building in the photo could have been a bunker from the Second World War, he adds.

Erich Wichmann, an epidemiologist at the National Research Center for Environment and Health in Neuherberg, and a member of Wassermann's commission who did not resign, says that Wassermann's conclusions are too speculative. Moreover, he says, independent labs have since failed to find unusual radioactive substances in the area.

A government spokesman says that Schleswig-Holstein has spent $€ 4.5$ million (US\$5.8 million) in 12 years to find the cause of the leukaemia cluster. The Wassermann commission was set to be wound up next February. 